\title{
Stormwater Efficiency of Bioretention Functions and Reactor Modelling Systems
}

\author{
Olatunde J Aladesote ${ }^{1}$, James Hunter ${ }^{2}$ \\ Department of Civil Engineering \\ Morgan State University \\ 1700 E Cold Spring Lane Baltimore \\ MD, USA 21251-0001
}

\begin{abstract}
Bioretention is a practical modern best management practices for stormwater control and are a conspicuous sort of vegetated stormwater foundation that functions for the different ecosystem. This paper discussion focusses on bioretention system functions (BSF) and reactor modeling (RM) review. Bioretention plays an essential role in carbon sequestration, as an alleviation process, to reduce global warming in the environment. Also, it functions for runoff infiltration, storage, and water uptake by vegetation. The base layer of a bioretention actively improves the denitrification capacity of the system and promotes the effective removal of phosphorus and nitrogen. Bioretention design soil ratio, plant types, and flow regime influence the efficiency of contaminants removal in the denitrification process. Bioretention beautifies the environment, and the utilization of compost in bioretention is on account of its water-holding and improved infiltration capacity, thereby improving water quality. The reactor modeling chemical description is through equations and kinetic models. The chemical computation of biological processes of pollutant nutrient removal from stormwater is in the form of a number equation. The models explored are first-order removal model, second order, plug flow patterns models, Monod and multiple Monod kinetics, continuous stirred-tank reactor model, and tank-in Series flow models.
\end{abstract}

Key Words: Bioretention System, Bioretention Functions, Nitrogen \& Phosphorus Removal, Reactor Modeling Equations.

\section{INTRODUCTION}

Urban rapid development has caused the expulsion of vegetation and the development of impermeable surfaces in urban communities, which are expanding the effect of urban stormwater on the ecosystem. Bioretention is a conspicuous sort of vegetated stormwater foundation that functions for different ecosystems. Bioretention frameworks are concave design land zones vegetated with chosen species and intended to get overflow from the catchment. Research has shown the effectiveness of modern best management practices methods used for stormwater control such as green roofs, bioswales, and constructed wetlands that include free water surface and subsurface flow systems [26]. Bioretention is built in small sizes to drain in a few hours with the utilization of soil ecosystems to oversee stormwater runoff. It can diminish the stormwater peak flow and volume [25]. Bioretention incorporates evapotranspiration and infiltration mechanism of action to decrease stormwater volumes.

Also, bioretention systems are urban stormwater best management practices (BMPs) that rely on terrestrial ecosystem functions to retain storm flows and reduce pollutant loads. It has indicated an incredible potential for stormwater quantity and quality control. The original hydrological characteristics of urban areas have undergone tremendous changes due to the rapid development of urban construction, and impervious surfaces have gradually replaced the natural green space. Modern urban construction methods have drastically reduced nitrogen retention capacity.

Stormwater runoff is a principal source of pollutants that impair water quality due to runoff variable flow rates and nitrogen concentration [2]. There are high concentrations of pollutants in stormwater runoff such as heavy metals, nutrients (phosphorus and nitrogen), pathogenic bacteria, suspended solids, toxic organic matters, oil, and organic carbon. Human activities, especially 
in industrialized urban areas, produced pollutants in the stormwater runoff [2]. Research studies have shown that $50 \%$ of nitrogen pollutions in waterways are from polluted runoff. Hence the need for low impact development (LID) strategies. Bioretention system is a type of LID and a stormwater control measure.

\subsection{Evolution of Bioretention}

Bioretention is a modern stormwater control method that evolved from Prince George's County (PGC) in Maryland in 1993, specifically in the Department of Environmental Resources [4, 7]. It is an essential fast-growing practice globally, mainly for small size drainage areas within the range of 0.25 and 1.0 acres. The size of the bioretention cell size is a function of the seepage zone and is usually about $7 \%$ of the seepage territory. The best located for a bioretention is in a depressed land area for adequate drainage. Another factor considered during bioretention system development is the ponding depth, which is about 6-12 inches. The depth functions for retention and faster stormwater infiltration into the soil within two days $[5,7]$.

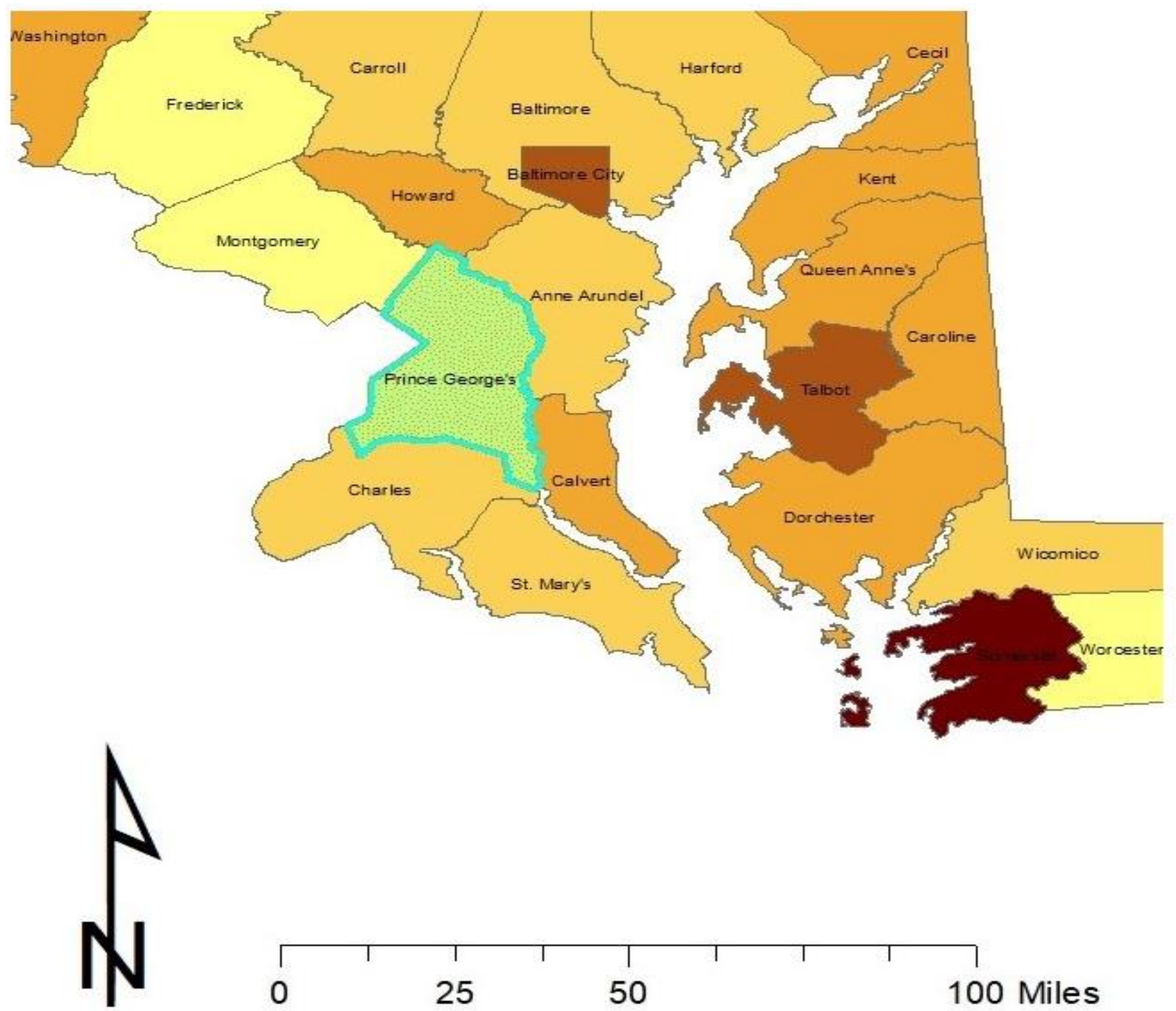

Figure 1. A map of PGC design by Author with ArcGIS 10.6.1.

\subsection{Bioretention System Design}

Bioretention is a design and constructed to have a soil media base, organic matter, plants, compost, stone, and mulch layer that removes contaminants. The physiochemical attributes of bioretention give differing utilization of explicit vegetation in the soil media, which can assist with advancing natural remediation of contaminants [23, 25]. Bioretention design includes a liner, an underdrain, and the soil layer composed of $80 \%$ sand with $20 \%$ red soil. Bioretention is a shallow depression located in upland areas. 
Also, many research studies found that the design of bioretention, including soil ration, plant types, and flow regime, has a significant influence on the efficiency of removing contaminants in the denitrification process [9, 11]. The structure comprises an overflow outlet developed, constructed, and connected to a drainage pipe that flows into the drainage framework, which will, in the long run, flow to streams. The base is built of a rock bed secured with a geotextile fabric that grants runoff flow and keeps the soil from the stone layer and the seepage pipe. Positioned on the textures of the structures is an engineered, designed soil media made of sand and compost blend mixture. The uppermost layer is various adornments ornaments planted in the sand compost blend [22].

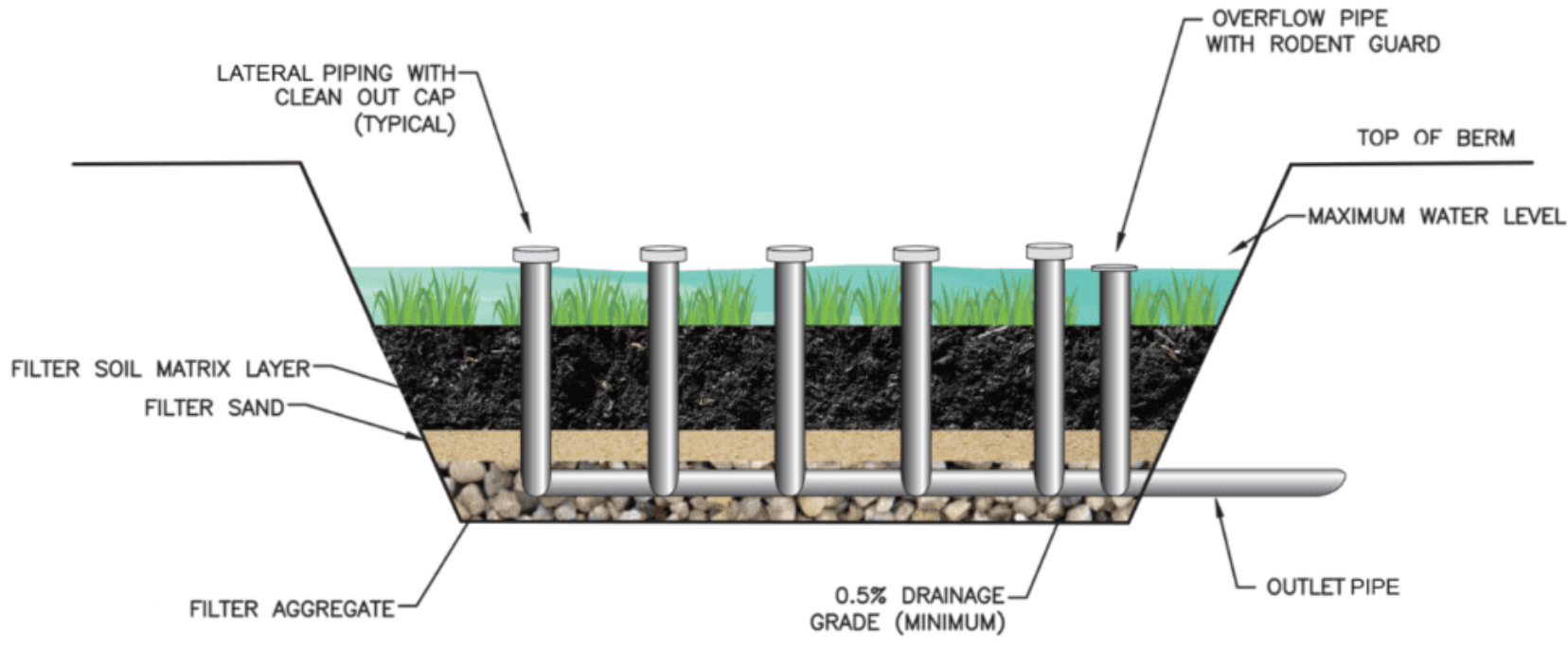

SIDE VEIW

Figure 2. A Vegetative Bioretention Design [22]

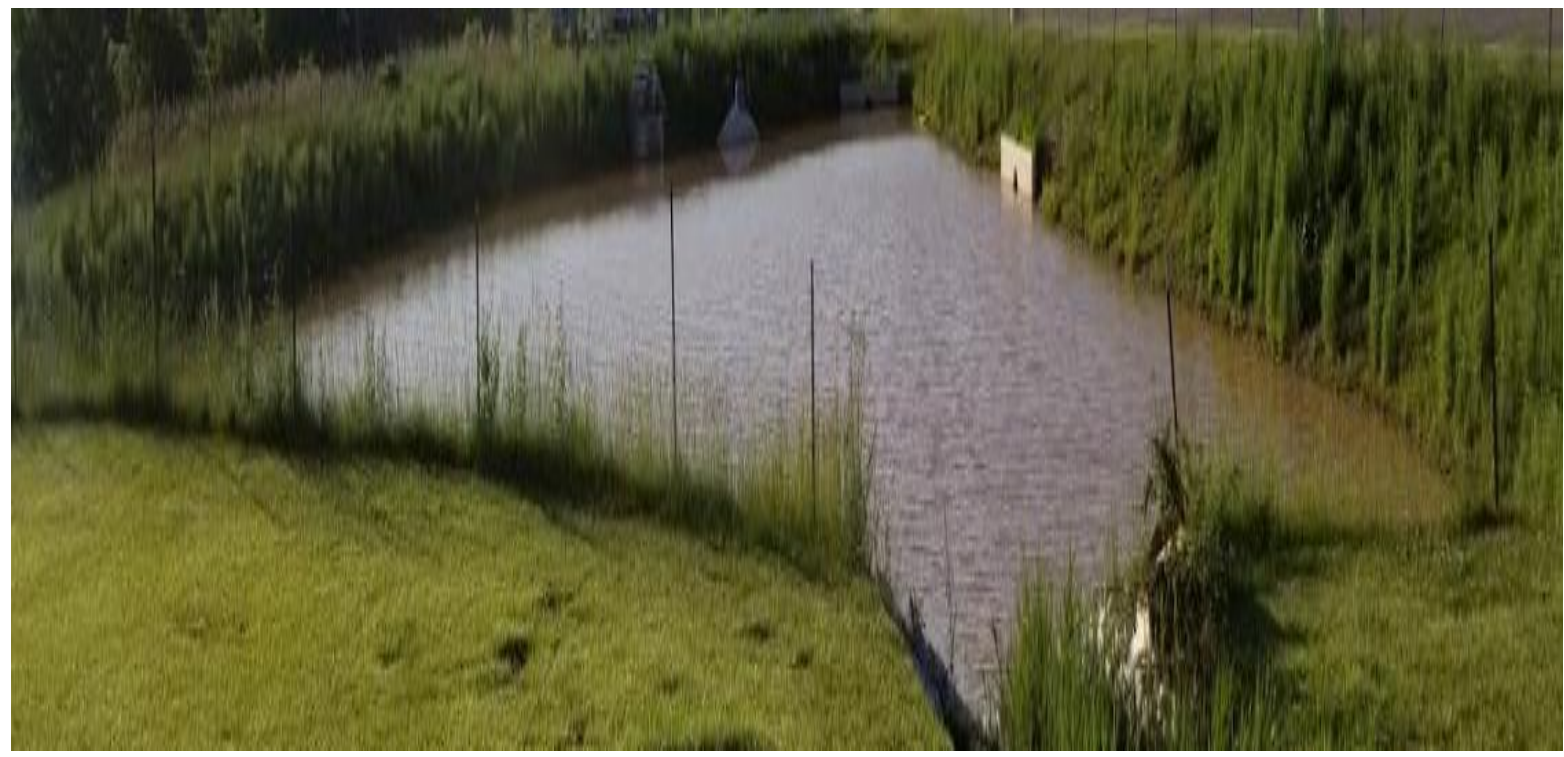

Figure 3. A Typical Bioretention Basin

Goh et al., conducted a laboratory study and found that additives can enhance bioretention media performance in treating nutrient-rich Stormwater [13]. Additives such as newspapers, coconut husk, and tire crumb useful in the system. However, more research is needed to justify the laboratory result in the field bioretention system. The type of plants used determines the long-term sustainable operation of the bioretention system. Selected plants such as reed are resistant to flood, drought-tolerance, and assist in erosion control on the sides of the basins [26-28]. 


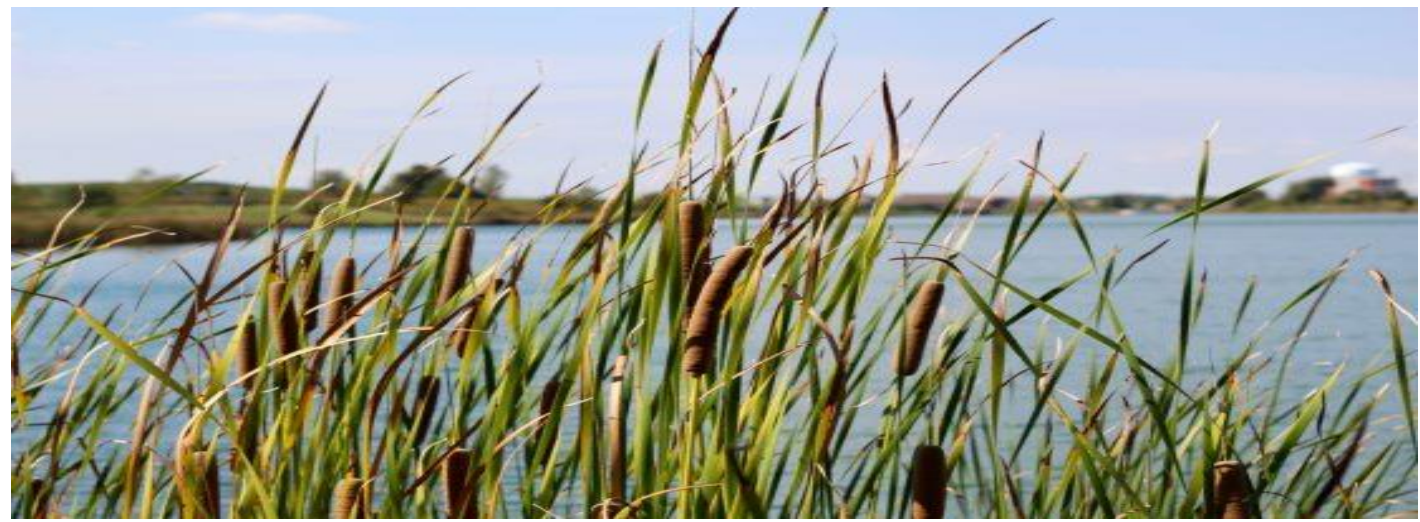

Figure 4. Reed Plant. Source: [28]

\section{FUNCTIONS OF BIORETENTION}

A study conducted by [18], in Australia, found carbon sequestration as one of the primary roles of bioretention in the modern era. Carbon sequestration, as an alleviation process, can function to reduce global warming in the environment. The research found that the bioretention basins showed a spatially uniform depositional pattern of carbon in their ponding territory [4, 6, 18]. It functions for runoff infiltration, storage, and water uptake by vegetation. Bioretention has high runoff retention, water purification, and flood peak reduction capacity [6]. The base layer of a bioretention actively improves the denitrification capacity of the system and promotes the effective removal of nitrogen and nitrate $[9,15]$. The design soil ratio, plant types, and flow regime influence the efficiency of contaminants removal in the denitrification process [9, 11]. Bioretention systems are highly efficient for nitrogen pollutant removal during runoff with $95 \%$ efficiencies [9].

Additionally, bioretention design functions to trap, filter, channel, and remove pollutants in runoff. The stones in the design, for the most part, slow the speed of flow of the runoff; it retains and absorbs contaminants before it channels to lakes. The soil filter and plants absorbed the runoff contaminants. It improves the nature of the environment with silt, nutrient, and sediment removal. Proof from several research studies conducted in various parts of the world shows that the primary nutrients in runoff are nitrogen and phosphorus. It beautifies the environment, and the utilization of compost in bioretention is on account of its water-holding and improved infiltration capacity, thereby improving water quality.

\subsection{Nitrogen Removal from Stormwater}

Stormwater is a significant nitrogen source in the urban ecosystem, which requires active treatment. Research studies found that the abundance of nitrogen is a crucial cause of waterways' eutrophication [26]. The submerged layer's design can enhance nitrogen removal efficiency in the bioretention system [16]. Further research comparative study is needed to analyze the permeability of the soil layer in a bioretention system.

\subsection{Nitrogen Removal Processes}

According to studies conducted by $[1,9,24]$, the natural ecosystem nitrogen elimination pathways are:

1) plant absorption assimilation,

2) leaching leakage,

3) microbial assimilation,

4) nitrification,

5) and denitrification

Nitrification is an oxidation procedure by which microorganisms in soil and water oxidize ammonia and ammonium ions to nitrites and nitrates. Nitrification helps plants absorb nitrates, and the process is in this equation:

$$
\mathrm{NH}_{3} \rightarrow \mathrm{NH}_{2} \mathrm{OH} \rightarrow \mathrm{NO}_{3^{-}} \rightarrow \mathrm{NO}_{2^{-}} \rightarrow \mathrm{N}_{2} \mathrm{O} \rightarrow \mathrm{N}_{2}
$$

Nitrification Denitrification.

Denitrification is a reduction process by which microorganisms reduce nitrates and nitrite to nitrous oxide and nitrogen. Nitrate is washout through the process of nitrification, and soil absorbed ammonia in stormwater with nitrate removal.

Studies have shown that bioretention systems are a highly efficient technical measure for nitrogen pollutant removal during runoff. Geographical, environmental conditions and slight differences in bioretention designs affect the denitrification performance of the system $[9,20]$. 


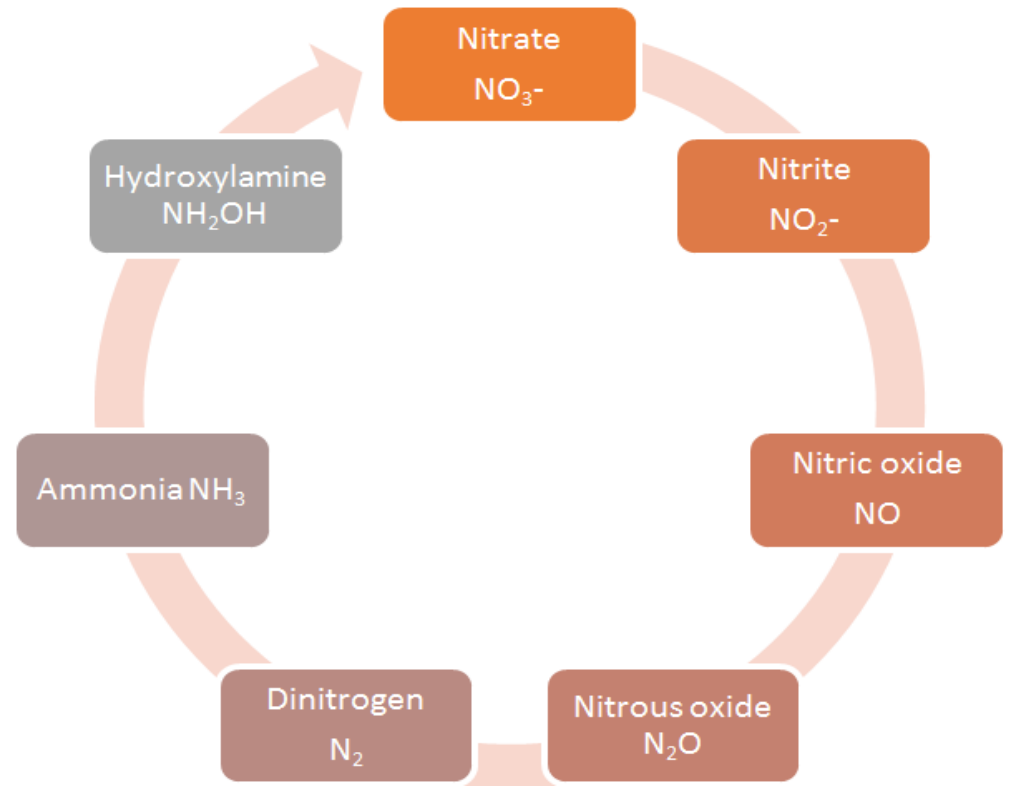

Figure 5. Microbial Nitrogen Cycle Pathway Design by Author

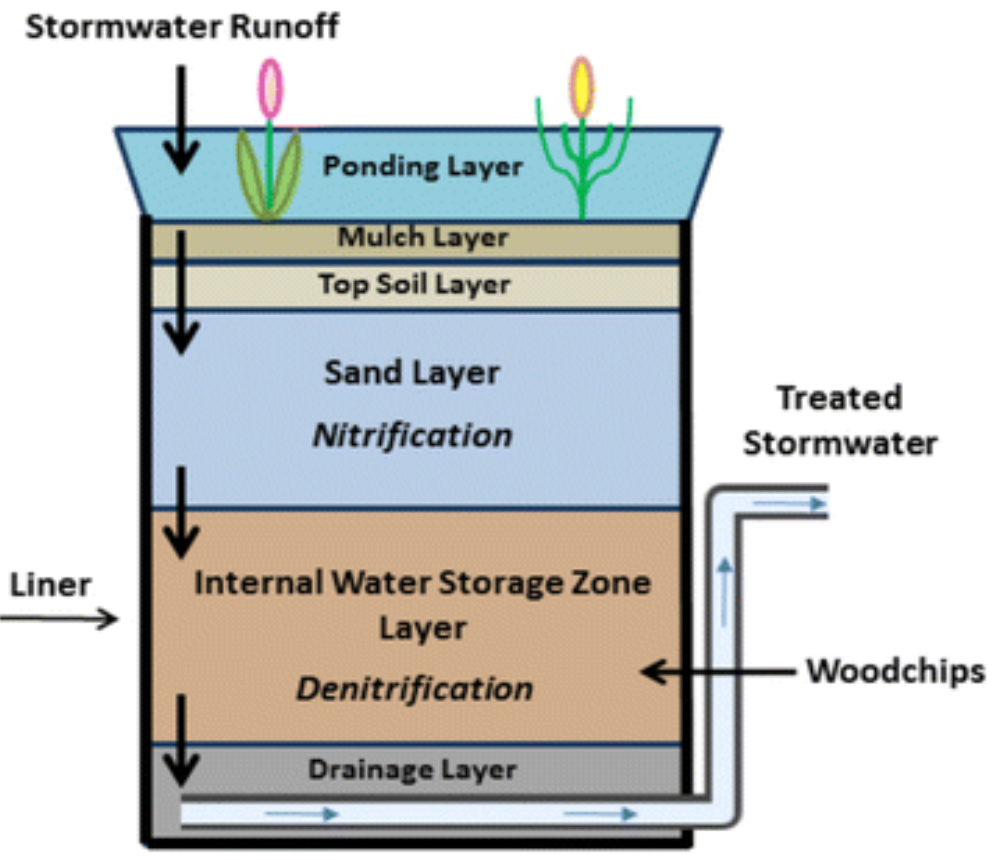

Figure 6. Bioretention layers with stormwater runoff infiltration through distinct pervious layers. Source: [20]

\subsection{Phosphorus Removal from Stormwater}

Research studies show that the bioretention system can effectively remove over $90 \%$ of total phosphorus (TP) in the runoff. The mechanism of bioretention phosphorus $(\mathrm{P})$ removal is residue adsorption in which orthophosphate PO4-3-P experiences a chemical reaction response with metal ions in the form of iron $(\mathrm{Fe})$, aluminum $(\mathrm{Al})$ or calcium $(\mathrm{Ca})$. The metals form insoluble compound precipitate expelled in water. Simulation and field studies on bioretention systems found that it can effectively eliminate TP in the runoff. Bioretention constructed with a blend of a little amount of organic matter and soil improve P expulsion capacity $[14,17,21]$.

\section{BIORETENTION REACTOR MODELING EQUATIONS}

Research studies showed that bioretention reactor modeling description is through equations and kinetic models. The computation of biological processes of pollutant removal such as nitrogen and phosphorus from stormwater is in the form of a number equation. Conducted studies proofed that kinetic models use include predicting the removal of nitrogen in stormwater treatment [12]. There are different models in a bioretention system including, the first order removal model, second-order, plug flow patterns models, Monod and multiple Monod kinetics, continuous stirred-tank reactor model, and tank-In Series (TIS) flow model. The design of the bioretention system is a determinant of the $\mathrm{K}$ rates and the mass area. The determinants of the equation 
processes are on the presence and types of vegetation in the bioretention order, oxygen transfer from plants to water, and pollutant loading factors from stormwater. The $\mathrm{k}$ rates can be area-based coefficients (kA). The reactor volume also contributes to the treatment methods and volume-based rate coefficients (KV) [3].

\subsection{First Order Reaction Models}

First Order Reaction Models is the most used kinetic model. Research studies on reactor models show that the rate coefficient, $\mathrm{k}$ is a factor that determines the speed of contaminant removal [12]. The chemical reactor is in the equation shown below:

$\mathrm{J}=\mathrm{k} \cdot \mathrm{C}$

Note that: $\mathrm{C}=$ concentration, $\mathrm{g} \cdot \mathrm{m}-3, \mathrm{~J}=$ removal per unit area, or load removed, $\mathrm{g} \cdot \mathrm{m}-2 \cdot \mathrm{d}-1, \mathrm{k}=$ rate coefficient, $\mathrm{m} \cdot \mathrm{d}-1$.

The models of bioretention are specific on the input to output data and based on the reactant concentration with the linear regression equations or first-order decomposition laws. The first order equation applied below:

$\mathrm{C}_{\text {out }} / \mathrm{C}_{\mathrm{in}}=\exp (-\mathrm{kA} / \mathrm{q})$

Note that $\mathrm{q}$ is the hydraulic loading rate in $\mathrm{m} \cdot \mathrm{d}-1$ and $\mathrm{kA}$ the decay constant in $\mathrm{m} \cdot \mathrm{d}-1$. Other forms of the first-order equation, which uses the hydraulic residence time (HRT, t) in days, is presented in [12].

$\mathrm{C}_{\text {out }} / \mathrm{C}_{\mathrm{in}}=\exp (-\mathrm{kvt})$

The hydraulic retention time (HRT) controls the use of the bioretention system for flow reduction [3]. The graphs below show the concentration of reactants against time in the first-order reaction. The plot of $\ln [\mathrm{A}]$ against time produces a straight line, and the slope of the line equal to $-\mathrm{k}[10]$.
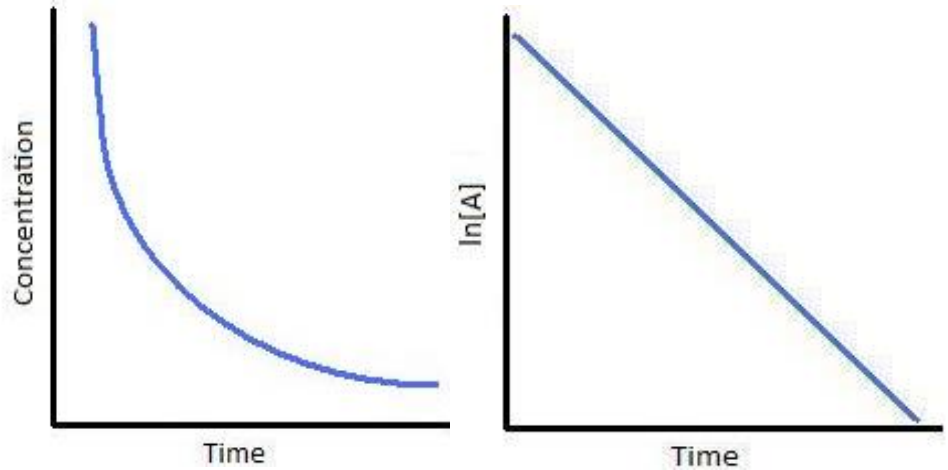

Figure 7. Graphical representation of the concentration of reactants versus time. Source: [10].

\subsection{Tank in Series Flow Model}

Researchers have shown that the tank-in Series flow model is a reaction kinetics with a little deviation from the plug flow model [19], and it is similar to the continuously stirred tank reactor (CSTR) functions [12]. $\mathrm{N}=\infty$ is equivalent to plug flow and $\mathrm{N}$ $=1$ is equivalent to a CSTR. First, the residence time distribution (RTD) is analyzed to determine the number of ideal tanks in series $\mathrm{n}[29]$ using this equation:

$$
E(t)=\frac{t^{n-1}}{(n-1) ! \tau_{!}^{n}} e^{-\frac{t}{\tau_{!}}}
$$

Where $\mathrm{E}(\mathrm{t})=$ quantity also referred to as the RTD function. $\mathrm{N}$ denotes the number of tanks in series that functions in the hydraulic performance of a bioretention. 
International Journal of Advances in Scientific Research and Engineering (ijasre), Vol 6 (11), November -2020
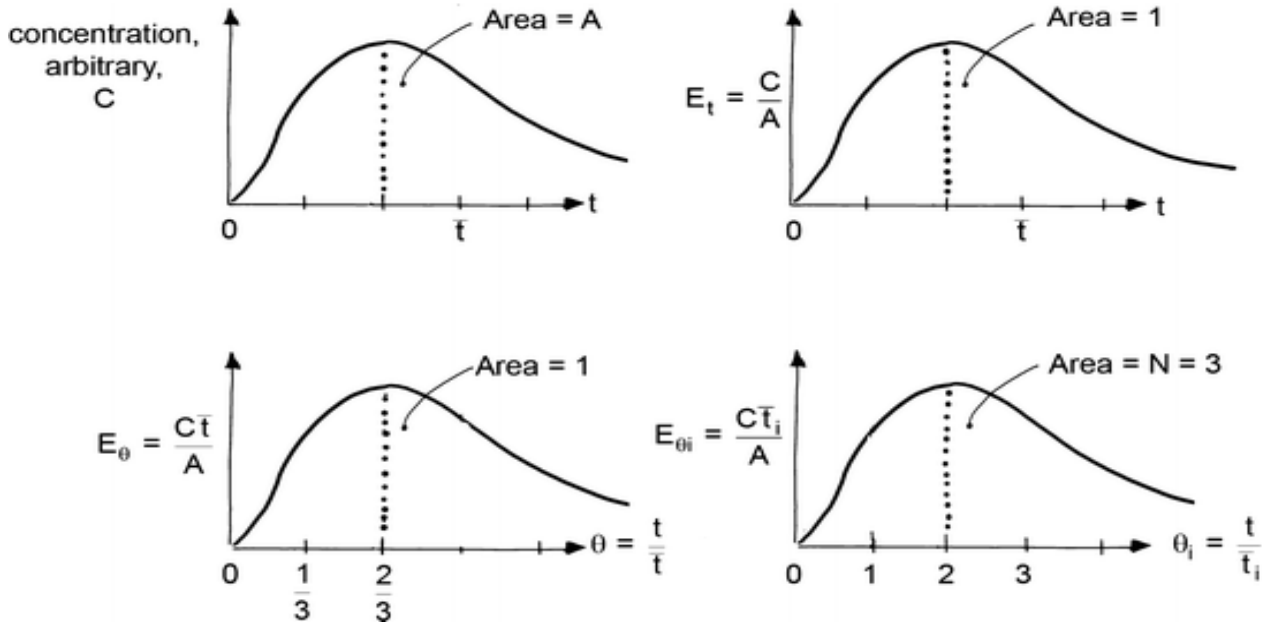

Figure 8. RTD curve for equal-size tanks in series model. Source: [19]

\subsection{Monod and Multiple Monod Reactor Models}

Monod and multiple Monod reactor models shows adequate comprehension of flow segments interrelations in bioretention system. The Monod model is an equation that is practically equivalent numerically to the Michaelis-Menten equation and is utilized in environmental engineering best management practices $[8,12]$

The Monod reactor kinetics [12]:

$$
\mathrm{dC} / \mathrm{dt}=-\mathrm{K}_{\max }\left(\mathrm{C}_{\text {out }} /\left(\mathrm{C}_{\text {half }}+\mathrm{C}_{\text {out }}\right)\right.
$$

Note that $\left(\mathrm{C}_{\text {out }}\right)$ is substrate concentration,

$\left(\mathrm{C}_{\text {half }}\right)$ is half saturation constant of limiting substrate,

$\left(\mathrm{K}_{\max }\right)$ is maximum pollutant removal rates

\section{CONCLUSION}

Explored in this paper are bioretention functions and reactor modeling. Bioretention system is a type of low impact development stormwater best management practice design that functions to control the harmful effects of urbanization on water quantity and quality. Its increasingly being used for pollutant removal mostly in densely populated communities where there are many impervious surfaces. Several research studies found that bioretention is efficient in controlling surface runoff peaks and volumes. The stormwater capture efficiency of bioretention systems varies based on design differences. Extensive laboratory and field studies show the uses of kinetic models in predicting the removal of nitrogen in the treatment of stormwater. Reactor modeling is an advanced computational enhancement to bioretention plan, design, support, operations, functions, and maintenance. Research findings have confirmed that the bioretention system is adequate for stormwater control and treatment. Future studies should conduct primary field research on the effect of amendments in enhancing media performance in a bioretention cell.

\section{REFERENCES}

[1] Akratos, C. S., Papaspyros, J. N., \& Tsihrintzis, V. A. (2009). Total nitrogen and ammonia removal prediction in horizontal subsurface flow constructed wetlands:Use of artificial neural networks and development of a design equation. Bioresource Technology, 100(2), 586 596. https://doi.org/10.1016/j.biortech.2008.06.071

[2] Aladesote, O. J., \& Hunter, J. (2019). Stormwater Management Utility Fees: A review. International Journal of Research Publication, 40(1). http://ijrp.org/paper detail/794

[3] Alikhani, J., Nietch, C., Jacobs, S., Shuster, B., \& Massoudieh, A. (2020). Modeling and design scenario analysis of longterm monitored Bioretention system for rainfall runoff reduction to combined sewer in Cincinnati, OH. Journal of Sustainable Water in the Built Environment, 6(2), 04019016. https://doi.org/10.1061/jswbay.0000903

[4] Craft, C., Vymazal, J., \& Kröpfelová, L. (2018). Carbon sequestration and nutrient accumulation in floodplain and depressional wetlands. Ecological Engineering, 114, 137-145. doi:10.1016/j.ecoleng.2017.06.034

[5] Davis, A. P., Hunt, W. F., Traver, R. G., \& Clar, M. (2009). Bioretention technology: Overview of current practice and future needs. Journal of Environmental Engineering, 135(3), 109-117. doi:10.1061/(asce)0733-9372(2009)135:3(109) 
[6] Davis, A. P., Traver, R. G., Hunt, W. F., Lee, R., Brown, R. A., \& Olszewski, J. M. (2012). Hydrologic performance of Bioretention storm-water control measures. Journal of Hydrologic Engineering, 17(5), 604-614. doi:10.1061/(asce)he.19435584.0000467

[7] Design manuals. (02/12/20). Prince George's County, MD | Official Website. https://www.princegeorgescountymd.gov/1478/Design-Manuals

[8] Doran, P. M. (2013). Bioprocess engineering principles. Academic Press.

[9] Fan, G., Li, Z., Wang, S., Huang, K., \& Luo, J. (2019). Migration and transformation of nitrogen in bioretention system during rainfall runoff. Chemosphere, 232, 54-62. doi:10.1016/j.chemosphere.2019.05.177

[10] First-order $\quad$ reactions. $\quad$ (2020, $\quad$ May $\quad 19)$ from https://chem.libretexts.org/Bookshelves/Physical_and_Theoretical_Chemistry_Textbook_Maps/Supplemental_Modules_(Ph ysical_and_Theoretical_Chemistry)/Kinetics/Reaction_Rates/First-Order_Reactions

[11] Fuchs, V. J., Gierke, J. S., \& Mihelcic, J. R. (2012). Laboratory investigation of ammonium and nitrate removal in verticalflow regimes in planted and unplanted wetland columns. Journal of Environmental Engineering, 138(12), 1227-1230. doi:10.1061/(asce)ee.1943-7870.0000588

[12] Gajewska, M., \& Skrzypiec, K. (2018). Kinetics of nitrogen removal processes in constructed wetlands. E3S Web of Conferences, 26, 00001. https://doi.org/10.1051/e3sconf/20182600001

[13] Goh, H., Zakaria, N., Lau, T., Foo, K., Chang, C., \& Leow, C. (2015). Mesocosm study of enhanced bioretention media in treating nutrient rich stormwater for mixed development area. Urban Water Journal, 14(2), 134-142. https://doi.org/10.1080/1573062x.2015.1076861

[14] Hatt, B. E., Fletcher, T. D., \& Deletic, A. (2009). Pollutant removal performance of field scale stormwater biofiltration systems. Water Science and Technology, 59(8), 1567-1576. https://doi.org/10.2166/wst.2009.173

[15] Hsieh, C., \& Davis, A. P. (2005). Evaluation and optimization of Bioretention media for treatment of urban storm water runoff. Journal of Environmental Engineering, 131(11), 1521-1531. doi:10.1061/(asce)0733-9372(2005)131:11(1521)

[16] Hsieh, C., Davis, A. P., \& Needelman, B. A. (2007). Nitrogen removal from urban stormwater runoff through layered Bioretention columns. Water Environment Research, 79(12), 2404-2411. https://doi.org/10.2175/106143007x183844

[17] Hunt, W. F., Jarrett, A. R., Smith, J. T., \& Sharkey, L. J. (2006). Evaluating Bioretention hydrology and nutrient removal at three field sites in North Carolina. Journal of Irrigation and Drainage Engineering, 132(6), 600-608. https://doi.org/10.1061/(asce)07339437(2006)132:6(600)

[18] Kavehei, E., Jenkins, G., Lemckert, C., \& Adame, M. (2019). Carbon stocks and sequestration of stormwater bioretention/biofiltration basins. Ecological Engineering, 138, 227-236. https://doi.org/10.1016/j.ecoleng.2019.07.006

[19] Levenspiel, O. (2011). Tracer technology: Modeling the flow of fluids. Springer Science \& Business Media.

[20] Lopez-Ponnada, E. V., Lynn, T. J., Peterson, M., Ergas, S. J., \& Mihelcic, J. R. (2017). Application of denitrifying wood chip bioreactors for management of residential nonpoint sources of nitrogen. Journal of Biological Engineering, 11(1). https://doi.org/10.1186/s13036-017-0057-4

[21] Lucas, W. C., \& Greenway, M. (2011). Phosphorus retention by Bioretention Mesocosms using media formulated for phosphorus sorption: Response to accelerated loads. Journal of Irrigation and Drainage Engineering, $137(3), 144153$. https://doi.org/10.1061/(asce)ir.1943-4774.0000243

[22] Manage stormwater run-off with vegetative Bioretention basins. (2019, March 5). Barker Lemar Companies. https://barkerlemarcompanies.com/2018/11/manage stormwater-run-off with vegetative-bioretention-basins/

[23] Morse, N. R., McPhillips, L. E., Shapleigh, J. P., \& Walter, M. T. (2017). The role of denitrification in stormwater detention basin treatment of nitrogen. Environmental Science \&Technology, 51 (14), 7928-7935. doi:10.1021/acs.est.7b01813

[24] Paredes, D., Kuschk, P., Stange, F., Müller, R., \& Köser, H. (2007). Model experiments on improving nitrogen removal in laboratory scale subsurface constructed wetlands by enhancing the anaerobic ammonia oxidation. Water Science and Technology, 56(3), 145 150. https://doi.org/10.2166/wst.2007.518

[25] Roy-Poirier, A., Champagne, P., \& Filion, Y. (2010). Review of Bioretention system research and design: Past, present, and 
International Journal of Advances in Scientific Research and Engineering (ijasre), Vol 6 (11), November -2020

future. Journal of Environmental Engineering, 136(9), 878 889. https://doi.org/10.1061/(asce)ee.1943 7870.0000227

[26] Wang, S., Lin, X., Yu, H., Wang, Z., Xia, H., An, J., \& Fan, G. (2017). Nitrogen removal from urban stormwater runoff by stepped bioretention systems. Ecological Engineering, 106, 340-348. https://doi.org/10.1016/j.ecoleng.2017.05.055

[27] Zhang, W., Sang, M., Che, W., \& Sun, H. (2019). Nutrient removal from urban stormwater runoff by an up-flow and mixedflow bioretention system. Environmental Science and Pollution Research, 26(17), 17731-17739. doi:10.1007/s11356-01905091-4

[28] Hunt, W. F., Lord, B., Loh, B., \& Sia, A. (2015). Plant selection for Bioretention systems and stormwater treatment practices. SpringerBriefs in Water Science and Technology. https://doi.org/10.1007/978-981-287-245-6

[29] University of Michigan. https://www.umich.edu (07/20)

${ }^{1}$ E-mail address: profolati@gmail.com. 